\title{
Absolute absorption cross-section and photolysis rate of $\mathbf{I}_{2}$
}

\author{
A. Saiz-Lopez ${ }^{1}$, R. W. Saunders ${ }^{1}$, D. M. Joseph ${ }^{1}$, S. H. Ashworth ${ }^{2}$, and J. M. C. Plane ${ }^{1}$ \\ ${ }^{1}$ School of Environmental Sciences, University of East Anglia, Norwich, UK \\ ${ }^{2}$ School of Chemical Sciences and Pharmacy, University of East Anglia, Norwich, UK
}

Received: 23 February 2004 - Published in Atmos. Chem. Phys. Discuss.: 5 May 2004

Revised: 27 July 2004 - Accepted: 20 August 2004 - Published: 1 September 2004

\begin{abstract}
Following recent observations of molecular iodine $\left(\mathrm{I}_{2}\right)$ in the coastal marine boundary layer (MBL) (SaizLopez and Plane, 2004), it has become important to determine the absolute absorption cross-section of $\mathrm{I}_{2}$ at reasonably high resolution, and also to evaluate the rate of photolysis of the molecule in the lower atmosphere. The absolute absorption cross-section $(\sigma)$ of gaseous $\mathrm{I}_{2}$ at room temperature and pressure (295 K, 760 Torr) was therefore measured between 182 and $750 \mathrm{~nm}$ using a Fourier Transform spectrometer at a resolution of $4 \mathrm{~cm}^{-1}(0.1 \mathrm{~nm}$ at $\lambda=500 \mathrm{~nm})$. The maximum absorption cross-section in the visible region was observed at $\lambda=533.0 \mathrm{~nm}$ to be $\sigma=(4.24 \pm 0.50) \times 10^{-18} \mathrm{~cm}^{2}$ molecule ${ }^{-1}$. The spectrum is available as supplementary material accompanying this paper. The photo-dissociation rate constant $(J)$ of gaseous $I_{2}$ was also measured directly in a solar simulator, yielding $J\left(\mathrm{I}_{2}\right)=0.12 \pm 0.03 \mathrm{~s}^{-1}$ for the lower troposphere. This is in excellent agreement with the value of $0.12 \pm 0.015 \mathrm{~s}^{-1}$ calculated using the measured absorption cross-section, terrestrial solar flux for clear sky conditions and assuming a photo-dissociation yield of unity. A twostream radiation transfer model was then used to determine the variation in photolysis rate with solar zenith angle (SZA), from which an analytic expression is derived for use in atmospheric models. Photolysis appears to be the dominant loss process for $\mathrm{I}_{2}$ during daytime, and hence an important source of iodine atoms in the lower atmosphere.
\end{abstract}

\section{Introduction}

Over the past two decades, there has been a growing interest in the role that iodine chemistry plays in a number of atmospheric processes, in particular the iodine-catalysed destruction of $\mathrm{O}_{3}$ in the troposphere (e.g. Jenkin et al., 1985;

Correspondence to: J. M. C. Plane

(j.plane@uea.ac.uk)
Chatfield and Crutzen, 1990; Davis et al., 1996; McFiggans et al., 2000). Furthermore, catalytic cycles involving chlorine and bromine appear not to be sufficient to explain $\mathrm{O}_{3}$ depletion in the lower stratosphere at low latitudes, leading to speculation that iodine also plays a role in stratospheric chemistry (Solomon et al., 1994; Bösch et al., 2003). Iodine may also be central to other atmospheric phenomena, including new particle formation in marine environments (O'Dowd et al., 2002a, 2002b; Mäkelä et al., 2002) and the enhancement of halogen/inter-halogen release via uptake on sea-salt aerosol (Vogt et al., 1999; McFiggans et al., 2002). The primary source of iodine in the atmosphere has been postulated to be the evasion of biogenic iodocarbons from the sea surface (Carpenter, 2003; Carpenter et al., 2003). $\mathrm{CH}_{3} \mathrm{I}, \mathrm{CH}_{2} \mathrm{I}_{2}$, $\mathrm{CH}_{2} \mathrm{IBr}$ and $\mathrm{CH}_{2} \mathrm{ICl}$ have all been detected in marine environments, with coastal emissions showing a direct correlation with tidal height and high solar irradiance (Carpenter et al., 1999, 2001). In terms of the open ocean, evaporation of molecular iodine $\left(\mathrm{I}_{2}\right)$ from the water surface, via oxidation of iodide ions in seawater under solar irradiation (Miyake and Tsunogai, 1963) or by reaction with atmospheric ozone (Garland and Curtis, 1981) have also been suggested.

The recent detection of molecular iodine at Mace Head, Ireland by differential optical absorption spectroscopy (DOAS), suggests that $I_{2}$ may also make a significant contribution to the overall iodine budget in the atmosphere (SaizLopez and Plane, 2004). $I_{2}$ was found at parts per trillion (ppt) levels in the coastal marine boundary layer (MBL), with a marked increase in concentration around low tide. This correlation between $\mathrm{I}_{2}$ production and tidal height suggests an oxidative stress mechanism within exposed macro-algal beds as the probable source of $I_{2}$ in the coastal MBL (McFiggans et al., 2004). In the troposphere, I atom production takes place through photo-dissociation of iodocarbons $\left(\mathrm{RI} / \mathrm{R}^{\prime} \mathrm{I}_{2}\right)$

$\mathrm{RI}+h v \longrightarrow \mathrm{R}+\mathrm{I}$ or $\mathrm{R}^{\prime} \mathrm{I}_{2}+h v \longrightarrow \mathrm{R}^{\prime} \mathrm{I}+\mathrm{I}$ 
The subsequent reaction of $\mathrm{I}$ atoms with atmospheric $\mathrm{O}_{3}$ leads to the formation of iodine monoxide (IO), which regenerates I atoms on photolysis,

$\mathrm{I}+\mathrm{O}_{3} \longrightarrow \mathrm{IO}+\mathrm{O}_{2}$

$\mathrm{IO}+h v \longrightarrow \mathrm{I}+\mathrm{O}$

or participates in iodine-catalysed $\mathrm{O}_{3}$ destruction cycles through reactions with $\mathrm{HO}_{2}$ (forming $\mathrm{HOI}$ ), $\mathrm{NO}_{2}$ (forming $\mathrm{IONO}_{2}$ ) or halogen oxides (Jenkin et al., 1985; Davis et al., 1996; McFiggans et al., 2000). The IO self-reaction has also been identified as an important process leading to the homogeneous nucleation of MBL aerosol. New particle formation is thought to occur via the polymeric build-up of iodine oxide aerosol formed by reactions of the iodine dioxide (OIO) radical, one of the products from the self-reaction of IO (Bloss et al., 2001; Hoffmann et al., 2001; Jimenez et al., 2003). The visible-infrared spectrum of $I_{2}$ has been the subject of numerous previous studies (Rabinowitch and Wood, 1936a; Goy and Pritchard, 1964; Ogryzlo and Thomas, 1965; Brewer and Tellinghuisen, 1972; Tellinghuisen, 1973). I 2 has a well-defined absorption structure in the visible region of the spectrum corresponding to the $\mathrm{B} \leftarrow \mathrm{X}$ electronic transition (Calvert and Pitts, 1966; Tellinghuisen, 1973). Photolysis in the visible region can proceed directly via three contributing transitions (Tellinghuisen, 1973; Gray et al., 2001):

$$
\begin{array}{ll}
\mathrm{I}_{2}+h v \longrightarrow \mathrm{I}+\mathrm{I} \quad\left(\mathrm{A}^{3} \Pi\left(1_{u}^{+}\right) \longleftarrow \mathrm{X}^{1} \Sigma_{g}^{+}\right) \\
\mathrm{I}_{2}+h v \longrightarrow \mathrm{I}+\mathrm{I}^{*} \quad\left(\mathrm{~B}^{3} \Pi\left(0_{u}^{+}\right) \longleftarrow \mathrm{X}^{1} \Sigma_{g}^{+}\right) \\
\mathrm{I}_{2}+h v \longrightarrow \mathrm{I}+\mathrm{I} \quad\left(\mathrm{C}^{1} \Pi_{u} \longleftarrow \mathrm{X}^{1} \Sigma_{g}^{+}\right)
\end{array}
$$

where I represents a ground state atom $\mathrm{I}\left({ }^{2} \mathrm{P}_{3 / 2}\right)$ and $\mathrm{I}^{*}$ denotes a meta-stable $\mathrm{I}\left({ }^{2} \mathrm{P}_{1 / 2}\right)$ atom. Subsequent relaxation from the meta-stable state to the ground state occurs through quenching processes or radiative decay $(\tau \sim 50 \mathrm{~ms}$, Okabe, 1978):

$$
\mathrm{I}^{*}\left({ }^{2} \mathrm{P}_{1 / 2}\right) \longrightarrow \mathrm{I}\left({ }^{2} \mathrm{P}_{3 / 2}\right)
$$

Note: the channel labelled R4b occurs only for excitation above the B state dissociation limit. Photolysis of $I_{2}$ in the atmosphere will generate I atoms through the following indirect channels,

$$
\mathrm{I}_{2}+h v \longrightarrow \mathrm{I}_{2}(B)+\mathrm{M} \longrightarrow \mathrm{I}+\mathrm{I}+\mathrm{M}
$$

collisional dissociation $\left(\mathrm{M}=\mathrm{N}_{2}\right.$ or $\left.\mathrm{O}_{2}\right)$

$$
\longrightarrow \mathrm{I}_{2}(B) \longrightarrow 2 \mathrm{I}
$$

spontaneous pre-dissociation

Notwithstanding this earlier work, a sufficiently high resolution absolute absorption cross-section for $\mathrm{I}_{2}$ suitable for
DOAS retrievals, and a measured rate of $\mathrm{I}_{2}$ photolysis (appropriate for atmospheric modelling), do not appear to be available in the literature. In this paper we will describe a measurement of the absolute absorption cross-section of $\mathrm{I}_{2}$ from the vacuum ultra-violet to the near infra-red. The photolysis rate of $I_{2}$, determined directly in a solar simulator, will then be compared with values calculated using the measured absorption spectrum and single and two-stream radiation models.

\section{Experimental}

\subsection{Cross-section determination}

The $\mathrm{I}_{2}$ spectrum was recorded using a Fourier Transform (FT) spectrometer (Bruker, Model IFS/66). Iodine crystals (Lancaster, 99.5\%) were placed in an optical cell and allowed to equilibrate at room temperature $(295 \mathrm{~K})$ and pressure (760 Torr of air) before each measurement was made. The spectrum was recorded in three overlapping regions: 182 $500 \mathrm{~nm}, \mathrm{GaP}$ diode detector, deuterium light source; 260 $555 \mathrm{~nm}, \mathrm{GaP}$ diode detector, tungsten lamp; 500-1100 nm, $\mathrm{Si}$ diode, Tungsten lamp. $\mathrm{A} \mathrm{CaF}_{2}$ beamsplitter was used in each case. All measurements were made at a resolution of $4 \mathrm{~cm}^{-1}(0.1 \mathrm{~nm}$ at $\lambda=500 \mathrm{~nm})$. The high resolution spectrum measured by the FT spectrometer was scaled in the continuum region to the average of a series of spectra recorded using a grating spectrometer (Acton SpectraPro SP-556-I, grating 1200 grooves $\mathrm{mm}^{-1}$, resolution $0.2 \mathrm{~nm}$ ), under carefully controlled conditions ( $295 \mathrm{~K}, 1$ atmosphere of air).

In order to calculate the absolute cross-section of $\mathrm{I}_{2}$ from its absorption spectrum, an accurate measurement of the vapour pressure of $\mathrm{I}_{2}$ is required. However, available data is sparse (see below), and so a new measurement was performed. Iodine crystals were placed in a $1 / 4^{\prime \prime}$ stainless steel U-tube, which was sealed at one end by a pair of Baratron pressure transducers, with 0-1000 Torr and 0-10 Torr ranges. The other end of the tube was attached to a vacuum line incorporating a diffusion pump, from which the tube could be isolated by a valve. The U-tube was immersed in water, in order to maintain it at a constant ambient temperature. The temperature of the water was monitored using a K-type thermocouple and was essentially constant $(<0.4 \mathrm{~K}$ variation) over the duration of the experiment.

The vapour pressure of the iodine was measured by first evacuating the tube as far as possible, then isolating it from the vacuum line and allowing the pressure to rise until it reached a constant value. This procedure was repeated until a consistent final pressure was observed. The vapour pressure of $\mathrm{I}_{2}$ at $295 \mathrm{~K}$ was found to be $0.225 \pm 0.020$ Torr, equivalent to a vapour concentration of $(7.4 \pm 0.7) \times 10^{15}$ molecules $\mathrm{cm}^{-3}$. This value is consistent with the vapour pressure of 0.30 Torr at $298 \mathrm{~K}$ from the JANAF Tables (Chase, 1998). In addition, our 


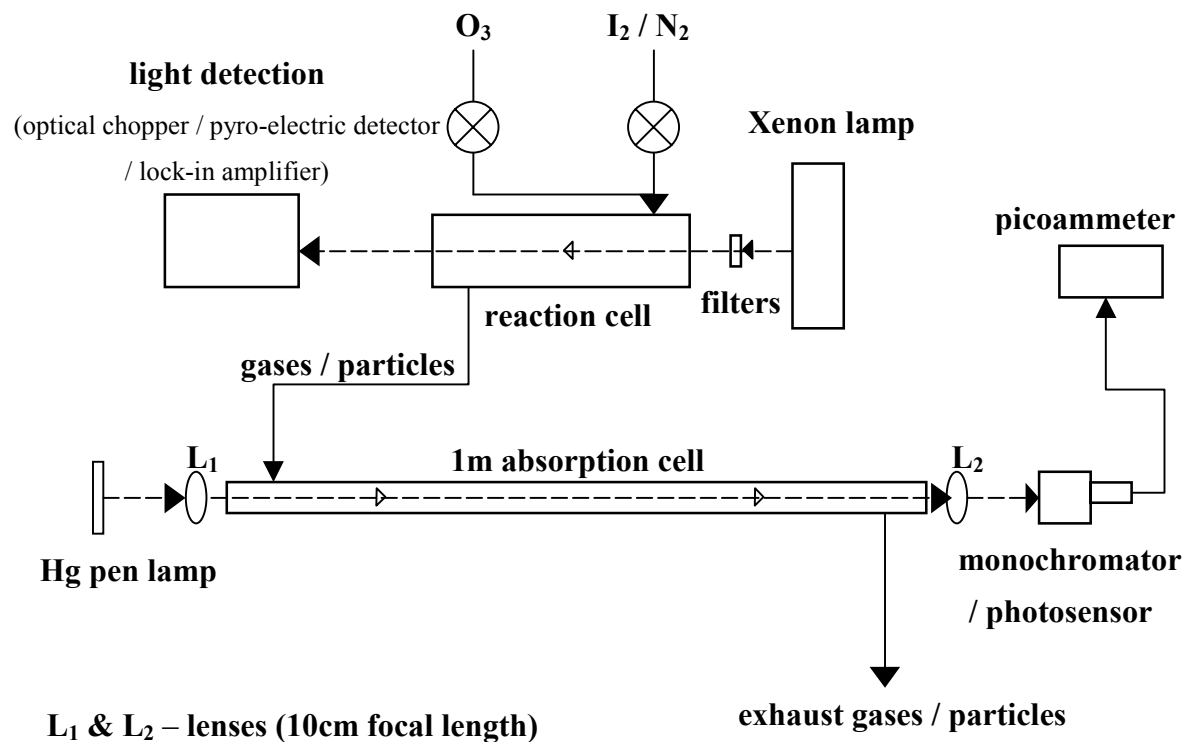

Fig. 1. Schematic of the optical absorption experiment used to measure the rate of photolysis of $I_{2}$.

value compares very well with a pressure of 0.24 Torr at $295 \mathrm{~K}$ evaluated from the measured data reported by Baxter et al. (1907), empirically fitted by Baxter and Grose (1915), and used by Shirley and Giauque (1959) in their measurements of thermodynamic properties of iodine.

\subsection{Rate of photolysis of $\mathrm{I}_{2}$}

Figure 1 is a schematic diagram of the experimental setup used. An excess of $\mathrm{O}_{3}\left(>1 \times 10^{16}\right.$ molecules $\left.\mathrm{cm}^{-3}\right)$, produced from an $\mathrm{O}_{2}$ flow through a coronadischarge, was used to ensure that the dominant loss process of $\mathrm{I}$ atoms was reaction with $\mathrm{O}_{3}\left(k_{295 \mathrm{~K}}\right.$ $\left(\mathrm{I}+\mathrm{O}_{3} \longrightarrow \mathrm{IO}+\mathrm{O}_{2}\right)=1.2 \times 10^{-12} \mathrm{~cm}^{3}$ molecule $^{-1} \mathrm{~s}^{-1} ; \quad \mathrm{De}$ More et al., 1997). Under these conditions, I atom recombination in the gas phase and on the cell walls was negligible. $\mathrm{I}_{2}$ vapour was generated by maintaining a steady low flow (5-10 standard $\mathrm{cm}^{3} \mathrm{~min}^{-1}$ ) of $\mathrm{N}_{2}$ across a few iodine crystals in a glass trap. The reaction took place in a glass cell (length $=25 \mathrm{~cm}$, volume $\approx 150 \mathrm{~cm}^{3}$ ) onto which quartz windows were mounted at each end to allow for irradiation by the light source and measurement of the light intensity. Flows of $\mathrm{N}_{2}\left(250-300\right.$ standard $\left.\mathrm{cm}^{3} \mathrm{~min}^{-1}\right)$ were also passed across each cell window to prevent any build-up of solid product on the window surfaces. The total gas flow through the cell produced a gas residence time of $12.5 \pm 2.5 \mathrm{~s}$.

Light from a "solar simulator" (Oriel Instruments, Model 91191), which employs a $1000 \mathrm{~W}$ Xenon lamp with an airmass optical filter to simulate the solar irradiance between 350 and $750 \mathrm{~nm}\left(\lambda_{\max }=583 \mathrm{~nm}\right)$, was directed through the cell. A condenser lens was used to ensure that the cell windows were illuminated completely with near-uniform light intensity. Neutral density filters were used to attenuate the light intensity, which was measured with a calibrated radiometer (Ramsden Scientific Instruments 550).

Downstream of the photolysis cell, the gas flowed through a $1 \mathrm{~m}$-long cell fitted with quartz windows, which was used to monitor $\mathrm{I}_{2}$ by absorption of the $546 \mathrm{~nm}$ emission line from a low pressure $\mathrm{Hg}$ lamp $\left(\sigma_{546 \mathrm{~nm}}=3.4 \times 10^{-18} \mathrm{~cm}^{2}\right.$ molecule $^{-1}$, from this study). This cell also contained 1 atmosphere of ambient gas (air) in order to prevent line saturation at the monitoring wavelength and so ensure that all absorbance measurements were within the Beer- Lambert regime. A monochromator (Optometrics, Model MC1-02, $1.2 \mathrm{~nm}$ resolution), with a side-on photomultiplier (Hamamatsu Photonics, Model H7710-12) and picoammeter allowed the $\mathrm{I}_{2}$ concentration to be determined from its measured absorbance over the range 0.01 to 0.08 , with a precision of $\pm 5 \%$. Both the photolysis cell and the absorption cell were covered with black cloth to minimise the effects of the laboratory lights.

\section{Results and Discussion}

\section{1 $\mathrm{I}_{2}$ absorption cross-section}

The absorption cross-section of $\mathrm{I}_{2}$ from $\lambda=182$ to $750 \mathrm{~nm}$ is shown in Fig. 2. The $182-499 \mathrm{~nm}$ region is dominated by the Cordes bands $\left(\mathrm{D}^{1} \Sigma_{u}^{+} \leftarrow \mathrm{X}^{1} \Sigma_{g}^{+}\right.$) between 182 and $200 \mathrm{~nm}$ (Myer and Samson, 1970; Okabe, 1978). This spectral region is clearly irrelevant with respect to photolysis in the lower troposphere, where only solar radiation at $\lambda>290 \mathrm{~nm}$ is available. In the $500-750 \mathrm{~nm}$ region of the $I_{2}$ spectrum, the underlying continuum is overlapped with vibrational structure between 500 and $650 \mathrm{~nm}$, which arises from the $\mathrm{B}^{3} \Pi\left(0_{u}^{+}\right) \leftarrow \mathrm{X}^{1} \Sigma_{g}^{+}$transition (Calvert and Pitts, 1966; Okabe, 1978). 


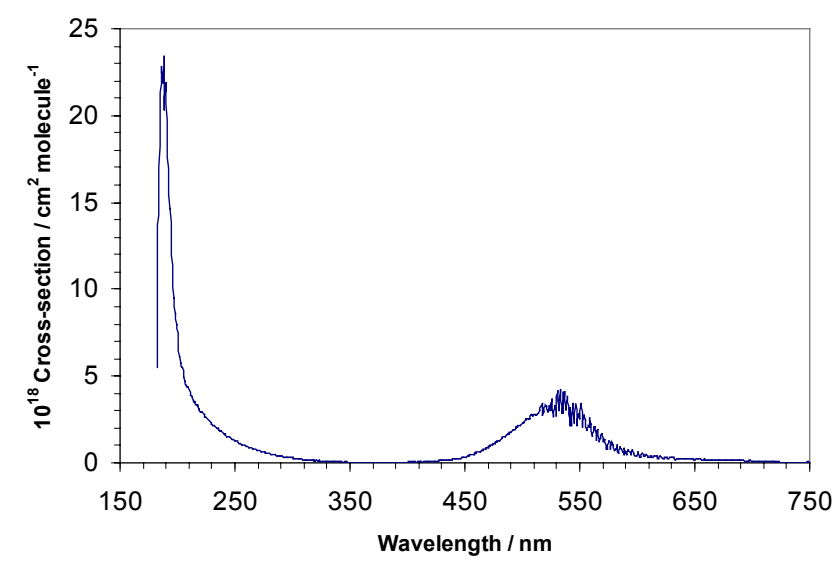

Fig. 2. Measured $I_{2}$ absorption cross-section shown over the full wavelength range at $1 \mathrm{~nm}$ resolution.

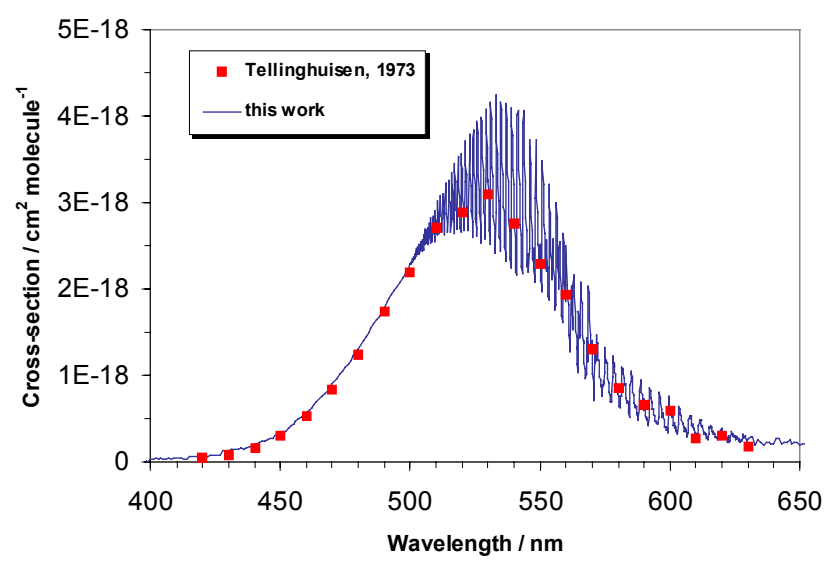

Fig. 3. Comparison of the $I_{2}$ spectrum from this study (400$500 \mathrm{~nm}$ at $1 \mathrm{~nm}$ resolution, $500-630 \mathrm{~nm}$ at $0.1 \mathrm{~nm}$ resolution and $630-650 \mathrm{~nm}$ at $1 \mathrm{~nm}$ resolution) with the values calculated from the data reported by Tellinghuisen (1973).

The effect of ambient pressure on the absorption spectrum of $\mathrm{I}_{2}$ has been discussed in a number of previous studies (Rabinowitch and Wood, 1936a; Goy and Pritchard, 1964; and Ogryzlo and Thomas, 1965). These investigations demonstrated that as the total gas pressure is raised (at constant $\mathrm{I}_{2}$ vapour pressure), absorption in the highly structured region from 500 to $570 \mathrm{~nm}$ initially increases before levelling off at a pressure of about 500 Torr. Pressure broadening is thought to prevent saturation at line centres in this region, so that cross-sections in the high pressure regime should be more accurate than those measured under low ambient gas pressure (Goy and Pritchard, 1964; Ogryzlo and Thomas, 1965; and Tellinghuisen, 1973). The last study to report absolute absorption cross sections for $\mathrm{I}_{2}$ was that of Tellinghuisen (1973), whose measurements in the structured region were made with no added bath gas but extrapolated to zero vapour pressure. This approach is equivalent to our method (high

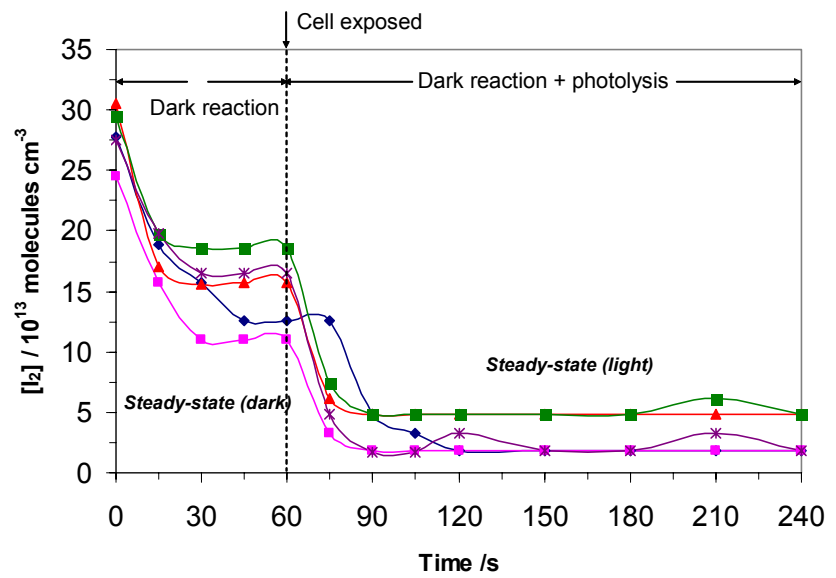

Fig. 4. Data sets for $\mathrm{I}_{2}+\mathrm{O}_{3}$ photo-oxidation at a cell irradiance of $1350 \mathrm{Wm}^{-2}$. The different symbols refer to individual experimental runs under the same conditions.

ambient gas pressure) in that it also prevents line saturation and allows for true extinction values to be obtained.

Figure 3 compares the cross-section from our study in the region $\lambda=400-650 \mathrm{~nm}$, with the values calculated from the data of Tellinghuisen which were measured at $2.6 \mathrm{~nm}$ resolution and reported at $10 \mathrm{~nm}$ intervals. This difference in resolution makes direct comparison difficult. However, our value at the continuum limit $(\sim 500 \mathrm{~nm})$ of $2.29 \times 10^{-18} \mathrm{~cm}^{2}$ molecule ${ }^{-1}$ agrees to within $4 \%$ of that of Tellinghuisen. This is as expected as absorption in the continuum region $(\lambda<500 \mathrm{~nm})$ should be independent of pressure. In the structured region at the wavelengths reported by Tellinghuisen, our values are generally in good agreement although because of the additional structure shown in our spectrum, we report higher cross-section values at wavelengths in between the data points of Tellinghuisen.

\subsection{Photolysis rate measurements}

Figure 4 illustrates the $I_{2}$ concentration measured downstream of the photolysis cell (see Fig. 1), as a function of time. The photolysis rate was determined from the following sequence of steps. Initially, $\left[\mathrm{I}_{2}\right]$ was measured with no $\mathrm{O}_{3}$ in the cell and the photolysis lamp blocked. When the $\mathrm{O}_{3}$ was then turned on, the dark (thermal) reaction of $\mathrm{I}_{2}$ with $\mathrm{O}_{3}$ $\left(k_{295 \mathrm{~K}}=3.8 \times 10^{-18} \mathrm{~cm}^{3}\right.$ molecule ${ }^{-1} \mathrm{~s}^{-1}$; Vikis and MacFarlane, 1985) proceeded until a (lower) steady-state $\left[\mathrm{I}_{2}\right]$ was reached (at 30-45 s). This concentration is termed $\left[\mathrm{I}_{2}\right]_{0}$ below. The next step was to unblock the photolysis light (at $60 \mathrm{~s}$ ) and irradiate the cell. The photo-oxidation of $I_{2}$ with $\mathrm{O}_{3}$ was then monitored over a 3 min period, with $\left[\mathrm{I}_{2}\right]$ reaching a new steady state (at 75-90 s).

The observed changes in absorption at $546 \mathrm{~nm}$ in the downstream absorption cell are the result of both $I_{2}$ photolysis and extinction by particles generated from condensation of the iodine oxide products in the photolysis cell 


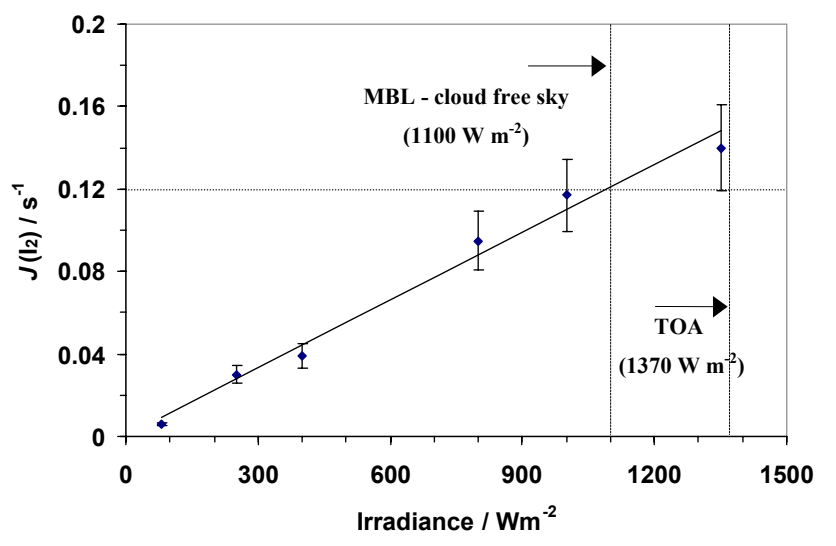

Fig. 5. Variation of the laboratory measured rate of $I_{2}$ photolysis with light irradiance. Data points shown correspond to the mean values calculated from 5 experiments run for each light irradiance value, all other reaction parameters being identical (error bars represent standard deviation in individual measurements). TOA (top of atmosphere) irradiance $=1$ solar constant.

(Cox and Coker, 1983; Vikis and MacFarlane, 1985; Jimenez et al., 2003; Burkholder et al., 2004). In order to correct for particle extinction, measurements under dark and light reaction conditions were also taken at three other Hg lamp emission lines $(365,405$ and $436 \mathrm{~nm})$, where absorption by $\mathrm{I}_{2}$ and $\mathrm{O}_{3}$ is negligible. The absorption dependencies for the dark and light reactions were found to vary as $\lambda^{-6}$ and $\lambda^{-5}$ respectively. These data were extrapolated to fit the particle absorption at $546 \mathrm{~nm}$ and the initial absorption measurements (due to $\mathrm{I}_{2}+$ particles) corrected accordingly. Particle extinction at $546 \mathrm{~nm}$ was found to be significant in both cases (30-35\% of the total measured absorption for the dark reaction, and $80-90 \%$ when photolysis of $I_{2}$ occurred). The rate at which $\mathrm{I}_{2}$ is removed from the reaction cell as a result of photolysis $\left(\mathrm{I}_{2}+h \nu \longrightarrow \mathrm{I}+\mathrm{I}\right)$ is described by the first-order expression

$\frac{\mathrm{d}\left[\mathrm{I}_{2}\right]}{\mathrm{d} t}=-J\left(\mathrm{I}_{2}\right)\left[\mathrm{I}_{2}\right]$

which integrates to give

$\left[\mathrm{I}_{2}\right]_{t}=\left[\mathrm{I}_{2}\right]_{0} \exp \left(-J\left(\mathrm{I}_{2}\right) t\right)$

where $\left[\mathrm{I}_{2}\right]_{t}$ is the concentration at time $(t),\left[\mathrm{I}_{2}\right]_{0}$ is the initial concentration and $J\left(\mathrm{I}_{2}\right)$ is the first-order rate of photolysis.

$J\left(\mathrm{I}_{2}\right)$ values were calculated from Eq. (3) by taking $\left[\mathrm{I}_{2}\right]_{0}$ as the dark reaction steady-state concentration, and $\left[\mathrm{I}_{2}\right]_{t}$ as the steady-state concentration after the $\mathrm{I}_{2}$ had been irradiated for $\tau=12.5 \pm 2.5 \mathrm{~s}$ (the residence time in the photolysis cell):

$J\left(\mathrm{I}_{2}\right)=\ln \left(\frac{\left[\mathrm{I}_{2}\right]_{0}}{\left[\mathrm{I}_{2}\right]_{t}}\right) \frac{1}{\tau}$

Figure 4 shows five data sets measured with an irradiance of $1350 \mathrm{Wm}^{-2}(\sim 1$ solar constant), from which a mean value for $J\left(\mathrm{I}_{2}\right)$ of $0.14 \pm 0.04 \mathrm{~s}^{-1}$ is obtained. Measurements were made at different irradiances in order to

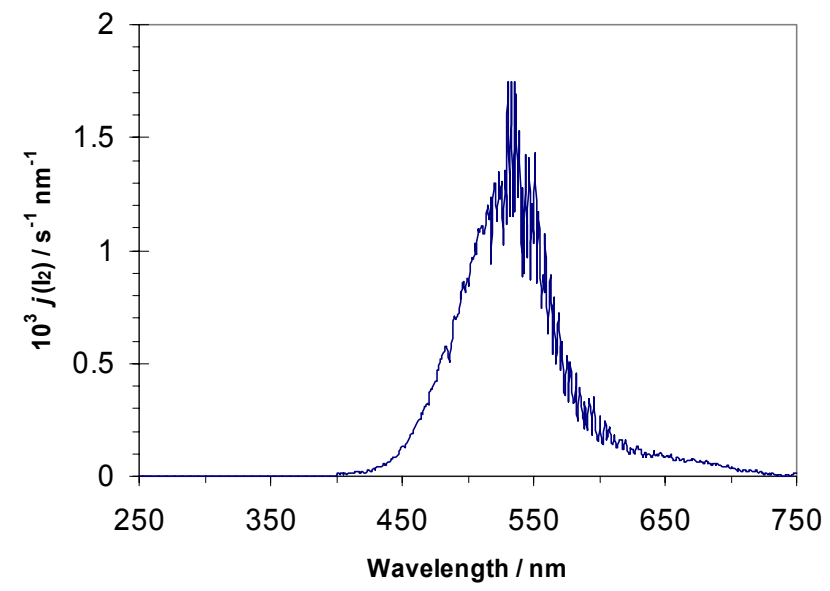

Fig. 6. Wavelength dependence of the $I_{2}$ photolysis rate in the lower atmosphere, calculated at $1 \mathrm{~nm}$ resolution. Values were convoluted using the measured $\mathrm{I}_{2}$ cross-section, solar flux data from Tobiska et al. (2000) (attenuated by atmospheric absorption) and a photodissociation yield of unity.

establish the variation of photolysis rate with light intensity (Fig. 5). The data shows a linear fit with a slope of $(1.10 \pm 0.07) \times 10^{-4} \mathrm{~s}^{-1} \mathrm{~W}^{-1} \mathrm{~m}^{2}$. A cloud free sky solar irradiance at the Earth's surface of $1100 \mathrm{~W} \mathrm{~m}^{-2}$ (assuming $20 \%$ attenuation by atmospheric absorption - Houghton, 2002), yields $J\left(\mathrm{I}_{2}\right)=0.12 \pm 0.03 \mathrm{~s}^{-1}$ for an overhead sun.

The total rate of photolysis of $\mathrm{I}_{2}$ can also be computed from the relation

$J(\lambda)=\int_{\lambda} F(\lambda) \times \sigma(\lambda) \times \varphi(\lambda) d \lambda=\int_{\lambda} j(\lambda) d \lambda$

where $F(\lambda)$ denotes the incident actinic flux (photons $\left.\mathrm{cm}^{-2} \mathrm{~s}^{-1} \mathrm{~nm}^{-1}\right), \sigma(\lambda)$ is the absorption cross-section $\left(\mathrm{cm}^{2}\right.$ molecule $\left.{ }^{-1}\right)$ and $\varphi(\lambda)$ is the quantum yield for photodissociation $(0<\varphi(\lambda)<1) . \varphi(\lambda)$ for $\mathrm{I}_{2}$ was set at a value of 1 for $290<\lambda<499 \mathrm{~nm}$ and for $651<\lambda<750 \mathrm{~nm}$. In the structured region of the spectrum $(500<\lambda<650 \mathrm{~nm})$, competing fluorescence $\left(\mathrm{I}_{2} *+\mathrm{M} \longrightarrow \mathrm{I}_{2}+\mathrm{M}+h v\right)$ can reduce the photodissociation yield from unity (Okabe, 1978). At low ambient gas pressure, the quantum yield in this region was reported as a function of wavelength by Brewer and Tellinghuisen (1972) such that $\varphi_{\min }=0.33$ at $590 \mathrm{~nm}$. However at high pressure ( $>150$ Torr), collisional quenching of excited $\mathrm{I}_{2}$ molecules (R6a) leads exclusively to dissociation to I atoms (Rabinowitch and Wood, 1936b). Therefore for our calculations, $\varphi(\lambda)$ was set at a value of 1 across the whole spectrum. Using the measured $\sigma(\lambda)$ from this study (Fig. 2) and extraterrestrial actinic flux $F_{0}(\lambda)$ from the SOLAR2000 irradiance model (Tobiska et al., 2000), corrected for atmospheric absorption, $j\left(\mathrm{I}_{2}\right)$ values with respect to the tropospheric boundary layer were calculated at a resolution of $1 \mathrm{~nm}$ (Fig. 6). Integration of the area under this plot gives a total $J\left(\mathrm{I}_{2}\right)=0.12 \pm 0.015 \mathrm{~s}^{-1}$ for an overhead sun. This estimate is in very good agreement with the measured value above. 


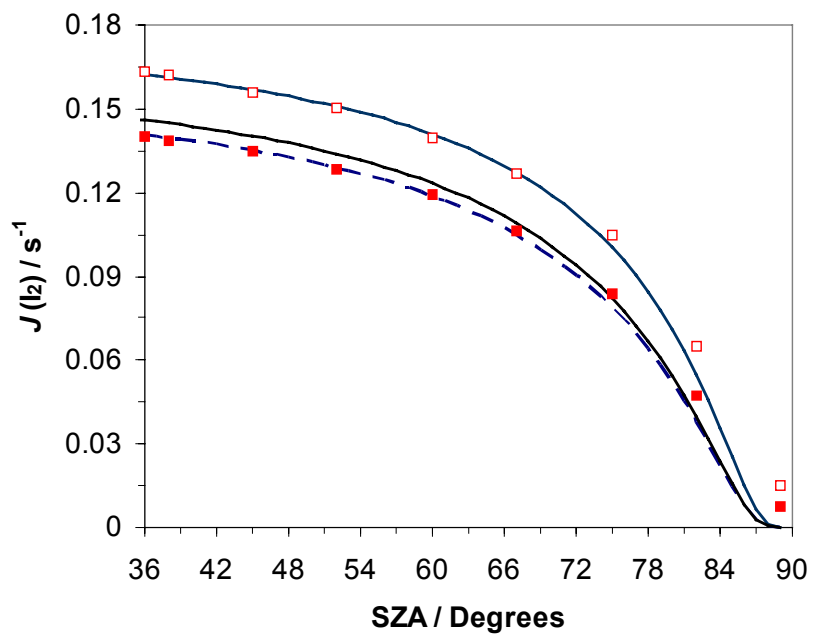

Fig. 7. Variation of $J\left(\mathrm{I}_{2}\right)$ with SZA. Values were calculated for a mid-latitude location $\left(53^{\circ} \mathrm{N}\right)$ in early August under cloud free conditions. The discrete data points are from the two-stream radiation model (filled: surface albedo $=0$, open: surface albedo $=0.1$ ). The dashed line is the fit to the points for zero albedo using Eq. (5) (see text) with $L=0.185, M=0.002$ and $N=0.221$, the solid blue line is the fit to the 0.1 albedo points ( $L=0.203, M=0.002, N=0.182$ ) and the solid black line is the data calculated for $L=0.1912, M=0.0019$ and $N=0.2185$ (Kanaya et al., 2003).

A two-stream radiation scheme (Thompson, 1984) was used to determine the rate of photolysis of $\mathrm{I}_{2}$ in the MBL as a function of solar zenith angle (SZA). Values corresponding to cloud-free conditions, were determined for early August (Julian Day 214) at Mace Head on the west coast of Ireland $\left(53^{\circ} 20^{\prime} \mathrm{N}\right)$. This location and time-of-year correspond to the reported observations of $I_{2}$ (Saiz-Lopez and Plane, 2004). Much of the work into iodine oxide particle production has also been carried out at this site (O'Dowd et al., 2002b). Using our measured absorption cross-section, $J\left(\mathrm{I}_{2}\right)=0.14 \mathrm{~s}^{-1}$ at midday $\left(\mathrm{SZA}=36^{\circ}\right)$ for a zero surface albedo. For a typical water surface albedo of $0.1, J\left(\mathrm{I}_{2}\right)$ increases to $0.16 \mathrm{~s}^{-1}$. Hough (1988) showed that for clear-sky conditions at an altitude of $0.5 \mathrm{~km}$, the variation between the photolysis rate of a species and the SZA can be described by:

$J(\mathrm{SZA})=L \cos (\mathrm{SZA})^{M} \exp (-N \sec (\mathrm{SZA}))$

or for $\mathrm{SZA}=0, J_{\max }=L \exp (-N)$

where $L, M$ and $N$ are parameters calculated by convoluting the absorption cross-section and quantum yield of a species with the solar actinic flux data, determined either by direct measurement using spectro-radiometry or calculated by radiative transfer modelling. Equation (5) has been used to generate $J$ values for a number of volatile organic species (VOC's) found in the troposphere (Jenkin et al., 1997) and more recently with respect to halogen-containing molecules including $\mathrm{I}_{2}, \mathrm{Br}_{2}$ and $\mathrm{Cl}_{2}$ (Kanaya et al., 2003). We have therefore fitted Eq. (5) to the clear-sky data obtained from

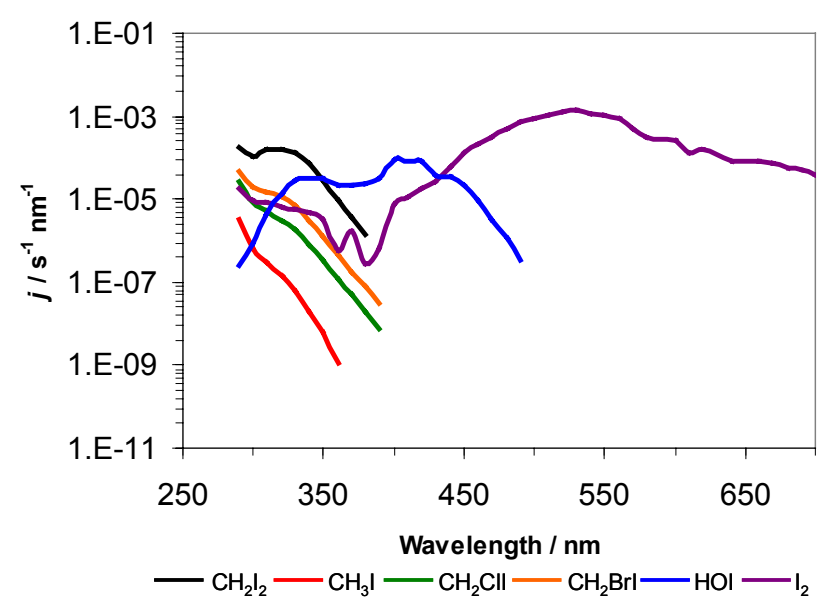

Fig. 8. Convoluted tropospheric photolysis rate variation (clear sky, overhead sun) for a number of iodine-containing species (absorption cross-sections at $10 \mathrm{~nm}$ intervals). Cross-section data was taken from the IUPAC gas kinetic database (with the exception of $\mathrm{I}_{2}$ for which our measured values were used), the photo-dissociation quantum yields were set to unity for all species, and direct actinic fluxes calculated from top of atmosphere data (corrected for atmospheric absorption). Integration across the wavelength range gives the photolysis rate constant $(J)$ for each species (see text for values).

the two-stream radiation code, yielding values of $L=0.185$, $M=0.002$ and $N=0.221$ for a zero surface albedo. Figure 7 illustrates that Eq. (5) provides a very satisfactory parameterisation of $J\left(\mathrm{I}_{2}\right)$ for $\mathrm{SZA}<80^{\circ}$. For a surface albedo of $0.1, L=0.203, M=0.002$ and $N=0.182$. Also shown in Fig. 7 is the variation in the photolysis rate calculated using the parameters given by Kanaya et al. (2003), which predicts $J\left(\mathrm{I}_{2}\right)=0.15 \mathrm{~s}^{-1}$ at a SZA of $36^{\circ}$. Hence our values and variation of $J$ with SZA are in good agreement with that of Kanaya et al. (2003) calculated using the cross-section values of Tellinghuisen and directly measured actinic flux.

The photolysis rates were calculated for $\mathrm{Cl}_{2}$ and $\mathrm{Br}_{2}$ using the data from Kanaya et al. (2003). Table 1 lists these values along with other parameters which clearly show the trends from $\mathrm{Cl}_{2} \rightarrow \mathrm{Br}_{2} \rightarrow \mathrm{I}_{2}$. Decreasing bond energies, increasing absorption cross-sections and the shift of peak absorption to the visible region of the solar spectrum lead to an increase in $J$ values. Finally, Fig. 8 summarises the convoluted photolysis rate constants as a function of wavelength for a number of gas-phase species which release atomic iodine upon photolysis in the MBL. The integrated $J$ values $(290 \mathrm{~nm}<\lambda<750 \mathrm{~nm})$ are $\left(\mathrm{s}^{-1}\right): 8.0 \times 10^{-3}$ $\left(\mathrm{CH}_{2} \mathrm{I}_{2}\right), 4.6 \times 10^{-5}\left(\mathrm{CH}_{3} \mathrm{I}\right), 4.5 \times 10^{-4}\left(\mathrm{CH}_{2} \mathrm{ClI}\right), 1.1 \times 10^{-3}$ $\left(\mathrm{CH}_{2} \mathrm{BrI}\right), 5.7 \times 10^{-3}(\mathrm{HOI})$ and $0.12\left(\mathrm{I}_{2}\right)$. 
Table 1. Trends in properties of the halogen diatomics.

\begin{tabular}{|c|c|c|c|c|}
\hline $\begin{array}{l}\text { Halogen } \\
\left(\mathrm{X}_{2}\right)\end{array}$ & $\begin{array}{l}\text { Bond Energy }{ }^{a} \\
\qquad\left(\mathrm{~kJ} \mathrm{~mol}^{-1}\right)\end{array}$ & $\begin{array}{c}10^{20} \sigma_{\max } \\
\left(\mathrm{cm}^{2} \text { molecule }^{-1}\right)\end{array}$ & $\begin{array}{l}\lambda \text { max } \\
(\mathrm{nm})\end{array}$ & $\begin{array}{c}J \\
\left(s^{-1}\right)\end{array}$ \\
\hline $\mathrm{Cl}_{2}$ & 243 & $26^{b}$ & $330^{b}$ & $0.0022^{c}$ \\
\hline $\mathrm{Br}_{2}$ & 193 & $68^{b}$ & $420^{b}$ & $0.034^{c}$ \\
\hline $\mathrm{I}_{2}$ & 151 & $424^{d}$ & $533^{d}$ & $0.15^{e}$ \\
\hline
\end{tabular}

$a$ at $298 \mathrm{~K}$ (CRC Handbook of Chemistry \& Physics, 2001)

$b$ at $298 \mathrm{~K}$, from the IUPAC gas kinetic database

${ }^{c}$ values calculated for $\mathrm{SZA}=0$ using parameters given in Kanaya et al. (2003)

$d$ measured in this study

${ }^{e}$ from this study for $\mathrm{SZA}=0$

\section{Conclusions}

A new measurement of the absolute absorption cross-section for $I_{2}$ over the wavelength range from $\lambda=182$ to $750 \mathrm{~nm}$ is reported for the conditions of $295 \mathrm{~K}$ and 760 Torr. We report a maximum absorption cross-section in the actinic wavelength range of $\sigma=(4.24 \pm 0.50) \times 10^{-18} \mathrm{~cm}^{2}$ molecule ${ }^{-1}$ at $\lambda=533.0 \mathrm{~nm}$. The $\mathrm{I}_{2}$ cross-section was measured at a resolution suitable for DOAS field measurements, and is provided as supplementary material to this paper.

The rapid photolysis of $I_{2}$ in the lower atmosphere (lifetime $=5-10 \mathrm{~s}$ for an overhead sun) results from the strong absorption of visible wavelengths $(400<\lambda<700 \mathrm{~nm})$ which penetrate down to the troposphere. Photolysis is therefore almost certainly the major loss process for $\mathrm{I}_{2}$ in the MBL during daytime, leading to the formation of iodine oxide aerosol and causing significant $\mathrm{O}_{3}$ depletion in the $\mathrm{MBL}$ (Saiz-Lopez and Plane, 2004).

\section{Supplementary Material}

The $\mathrm{I}_{2}$ absorption cross-section from $182-750 \mathrm{~nm}$ reported in this study is available in spreadsheet format.

Acknowledgements. This work was supported by the UK Natural Environment Research Council. The authors wish to thank Gordon McFiggans for helpful discussions on the use of the radiation transfer model, and Tomas Vondrak for providing the SOLAR2000 actinic flux data.

Edited by: R. A. Cox

\section{References}

Baxter, G. P., Hickey, C. H., and Holmes, W. C.: The vapour pressure of iodine, J. Am. Chem. Soc., 29, 127-136, 1907.

Baxter, G. P. and Grose, M. R.: The vapour pressure of iodine between $50^{\circ}$ and $95^{\circ}$, J. Am. Chem. Soc., 37, 1061-1072, 1915.

Bloss, W. J., Rowley, D. M., Cox, R. A., and Jones, R. L.: Kinetics and products of the IO self-reaction, J. Phys. Chem., 105, 78407854, 2001.

Bösch, H., Camy-Peyret, C., Chipperfield, M. P., Fitzenberger, R., Harder, H., Platt, U., and Pfeilsticker, K.: Upper limits of stratospheric IO and OIO inferred from center-to-limb darkeningcorrected balloon-borne solar occultation visible spectra: Implications for total gaseous iodine and stratospheric ozone, J. Geophys. Res., 108, 4455, doi:10.1029/2002JD003078, 2003.

Brewer, L. and Tellinghuisen, J.: Quantum yield for unimolecular dissociation of $\mathrm{I}_{2}$ in visible absorption, J. Chem. Phys., 56, 39293938, 1972.

Burkholder, J. B., Curtius, J., Ravishankara, A. R., and Lovejoy, E. R.: Laboratory studies of the homogeneous nucleation of iodine oxides, Atmos. Chem. Phys., 4, 19-34, 2004, SRef-ID: 1680-7324/acp/2004-4-19.

Calvert, J. G. and Pitts, J. N.: Photochemistry, Wiley, New York, 1966.

Carpenter, L. J., Sturges, W. T., Penkett, S. A., Liss, P. S., Alicke, B., Hebestreit, K., and Platt, U.: Short-lived alkyl iodides and bromides at Mace Head, Ireland: links to biogenic sources and halogen oxide production, J. Geophys. Res., 104, 1679-1689, 1999.

Carpenter, L. J., Hebestreit, K., Platt, U., and Liss, P. S.: Coastal zone production of IO precursors: A 2-dimensional study, Atmos. Chem. Phys., 1, 9-18, 2001,

SRef-ID: 1680-7324/acp/2001-1-9.

Carpenter, L. J.: Iodine in the marine boundary layer, Chem. Rev., 103, 4953-4962, 2003.

Carpenter, L. J., Liss, P. S., and Penkett, S. A.: Marine organohalogens in the atmosphere over the Atlantic and Southern oceans, J. Geophys. Res., 108, 4256, doi:10.1029/2002JD002769, 2003.

Chase Jr., M. W.: NIST JANAF Thermochemical Tables, Fourth Edition, J. Phys. Chem. Ref. Data, Monograph 9, 1998.

Chatfield, R. B. and Crutzen, P. J.: Are there interactions of iodine and sulfur species in marine air photochemistry? J. Geophys. Res., 95, 22 319-22 341, 1990.

Cox, R. A. and Coker, G. B.: Absorption cross-section and kinetics of $\mathrm{IO}$ in the photolysis of $\mathrm{CH}_{3} \mathrm{I}$ in the presence of ozone, J. Phys. Chem., 87, 4478-4484, 1983.

CRC Handbook of Chemistry and Physics: 82nd Edition, CRC Press, Boca Raton, 2001-2002.

Davis, D., Crawford, J., Liu, S., McKeen, S., Bandy, A., Thornton, D., Rowland, F., and Blake, D.: Potential impact of iodine on tropospheric levels of ozone and other critical oxidants, J. Geophys. Res., 101, 2135-2147, 1996.

DeMore, W. B., Sander, S. P., Golden, D. M., Hampson, R. F., Kurylo, M. J., Howard, C. J., Ravishankara, A. R., Kolb, C. E., and Molina, M. J.: Chemical kinetics and photochemical data for use in stratospheric modelling: Evaluation Number 12, JPL Publ., 97-4, 1997.

Garland, J. A. and Curtis, H.: Emission of iodine from the sea surface in the presence of ozone, J. Geophys. Res., 86, 3183-3186, 1981. 
Goy, C. A. and Pritchard, C. A.: Pressure dependence of the visible iodine bands, J. Mol. Spectrosc., 12, 38-44, 1964.

Gray, R. I., Luckett, K. M., and Tellinghuisen, J.: Component analysis of the visible absorption spectra of $\mathrm{I}_{2}$ and $\mathrm{Br}_{2}$ in inert solutions: A critique of band decomposition by least-squares fitting, J. Phys. Chem., 105, 11 183-11 191, 2001.

Hoffmann, T., O'Dowd, C. D., and Seinfeld, J. H.: Iodine oxide homogeneous nucleation: An explanation for coastal new particle production, Geophys. Res. Lett., 28(10), 1949-1952, 2001.

Hough, A. M.: The calculation of photolysis rates for use in global tropospheric modelling studies, AERE Report R-13259 (HMSO), London, 1988.

Houghton, J.: The physics of atmospheres, 3rd Edition, Cambridge Uni. Press, Cambridge, 2002.

International Union of Pure and Applied Chemistry (IUPAC): Subcommittee for gas kinetic data evaluation, www.iupac-kinetic.ch. cam.ac.uk.

Jenkin, M. E., Cox, R. A., and Candeland, D. E.: Photochemical aspects of tropospheric iodine behaviour, J. Atmos. Chem., 2 (4), 359-375, 1985.

Jenkin, M. E., Saunders, S. M., and Pilling, M. J.: The tropospheric degradation of volatile organic compounds: a protocol for mechanism development, Atmos. Env., 31, 81-104, 1997.

Jimenez, J. L., Bahreini, R., Cocker III, D. R., Zhuang, H., Varutbangkul, V., Flagan, R. C., Seinfeld, J. H., O'Dowd, C. D., and Hoffmann, T.: New particle formation from photooxidation of diiodomethane $\left(\mathrm{CH}_{2} \mathrm{I}_{2}\right)$, J. Geophys. Res., 108, D10, 4318, doi:10.1029/2002JD002452, 2003.

Kanaya, Y., Kajii, Y., and Akimoto, H.: Solar actinic flux and photolysis frequency determinations by radiometers and a radiative transfer model at Rishiri Island: comparisons, cloud effects and detection of an aerosol plume from Russian forest fires, Atmos. Env., 37, 2463-2475, 2003.

McFiggans, G., Plane, J. M. C., Allan, B. J., Carpenter, L. J., Coe, H., and O'Dowd, C.: A modeling study of iodine chemistry in the marine boundary layer, J. Geophys. Res., 105, 14371-14385, 2000.

McFiggans, G., Cox, R. A., Mössinger, J. C., Allan, B. J., and Plane, J. M. C.: Active chlorine release from marine aerosols: Roles for reactive iodine and nitrogen species, J. Geophys. Res., 107, D15, 4271, doi:10.1029/2001JD000383, 2002.

McFiggans, G., Coe, H., Burgess, R., Allan, A., Cubison, M., Alfarra, M. R., Saunders, R., Saiz-Lopez, A., Plane, J. M. C., Wevill, D. J., Carpenter, L. J., Rickard, A. R., and Monks, P. S.: Direct evidence for coastal iodine particles from Laminaria macroalgae - linkage to emissions of molecular iodine, Atmos. Chem. Phys., 4, 701-713, 2004,

SRef-ID: 1680-7324/acp/2004-4-701.

Mäkelä, J. M., Hoffmann, T., Holzke, C., Väkevä, M., Suni, T., Mattila, T., Aalto, P. P., Tapper, U., Kaupinnen, E. I., and O'Dowd, C. D.: Biogenic iodine emissions and identification of end-products in coastal ultrafine particles during nucleation bursts, J. Geophys. Res., 107, D19, 8110, doi:10.1029/2001JD000580, 2002.
Miyake, Y. and Tsunogai, S.: Evaporation of iodine from the ocean, J. Geophys. Res., 68, 3989-3993, 1963.

Myer, J. A. and Samson, J. A. R.: Absorption cross section and photoionization yield of $\mathrm{I}_{2}$ between 1050 and $2200 \AA$ \&. J. Chem. Phys., 52, 716-718, 1970.

O’Dowd, C. D., Jimenez, J. L., Bahreini, R., Flagan, R. C., Seinfeld, J. H., Hameri, K., Pirjola. L., Kulmala, M., Jennings, S. G., and Hoffmann, T.: Marine aerosol formation from biogenic iodine emissions, Nature, 417, 632-636, 2002a.

O’Dowd., C. D., Hämeri, K., Mäkelä, J. M., Pirjola, L., Kulmala, M., Gerard Jennings, S., Berresheim, H., Hansson, H.-C., de Leeuw, G., Kunz, G. J., Allen, A. G., Hewitt, C. N., Jackson, A., Viisanen, Y., and Hoffmann, T.: A dedicated study of new particle formation and fate in the coastal environment (PARFORCE): Overview of objectives and achievements, J. Geophys., Res., 107, D19, 8108, doi:10.1029/2001JD000555, 2002b.

Ogryzlo, E. A. and Thomas, G. E.: Pressure dependence of the visible absorption bands of molecular iodine, J. Mol. Spectrosc., 17, 198-202, 1965.

Okabe, H.: Photochemistry of small molecules, John Wiley \& Sons, New York, 1978.

Rabinowitch, E. and Wood, W. C.: The extinction coefficients of iodine and other halogens, Trans. Faraday Soc., 32, 540-546, 1936 a.

Rabinowitch, E., and Wood, W. C.: Dissociation of excited iodine molecules, J. Chem. Phys., 4, 358-362, 1936b.

Saiz-Lopez, A. and Plane, J. M. C.: Novel iodine chemistry in the marine boundary layer, Geophys. Res. Letts., 31, L04112, doi:10.1029/2003GL019215, 2004.

Shirley, D. A. and Giauque, W. F.: The entropy of iodine. Heat capacity from 13 to $327 \mathrm{~K}$. Heat of sublimation, J. Am. Chem. Soc., 81, 4778-4779, 1959.

Solomon, S., Garcia, R. R., and Ravishankara, A. R.: On the role of iodine in ozone depletion, J. Geophys. Res., 99, 20 491-20 499, 1994.

Tellinghuisen, J.: Resolution of the visible-infrared absorption spectrum of $\mathrm{I}_{2}$ into three contributing transitions, J. Chem. Phys., 58, 2821-2834, 1973.

Thompson, A. M.: The effect of clouds on photolysis rates and ozone formation in the unpolluted troposphere, J. Geophys. Res., 89, 1341-1349, 1984.

Tobiska, W. K., Woods, T., Eparvier, F., Viereck, R., Floyd, L., Bouwer, D., Rottman, G., and White, O. R.: The SOLAR2000 empirical solar irradiance model and forecast tool, J. Atmos. Solar-Terr. Phys., 62, 1233-1250, 2000.

Vikis, A. C. and MacFarlane, B.: Reaction of iodine with ozone in the gas phase, J. Phys. Chem., 89, 812-815, 1985.

Vogt, R., Sander, R., Von Glasow, R., and Crutzen, P. J.: Iodine chemistry and its role in halogen activation and ozone loss in the marine boundary layer: A model study, J. Atmos. Chem., 32, 375-395, 1999. 